Knowledge Management

Research \& Practice

\title{
GENERATING CUSTOMER VALUE THROUGH THE BOOSTING OF RELATIONSHIPS AND ORGANIZATIONAL INNOVATIVENESS.
}

\begin{tabular}{|c|l|}
\hline Journal: & Knowledge Management Research \& Practice \\
\hline Manuscript ID & TKMR-2018-OA-0028.R1 \\
\hline Manuscript Type: & Original Article \\
\hline Keywords: & $\begin{array}{l}\text { relationship learning, organizational innovativeness, customer value, } \\
\text { partial least squares }\end{array}$ \\
& $\begin{array}{l}\text { This study aims to shed light on the question of how companies can } \\
\text { generate customer value within the current increasingly dynamic, } \\
\text { turbulent and hypercompetitive settings. With this purpose, we intend to } \\
\text { examine whether relationship learning mechanisms and organizational } \\
\text { innovativeness are actually key drivers of customer value. Concretely, } \\
\text { this paper proposes and tests a mediation model that links relationship } \\
\text { learning, organizational innovativeness and customer value. In order to } \\
\text { test the research model and hypotheses posited in this study, we rely on } \\
\text { the use of partial least squares (PLS) path-modeling, a variance-based } \\
\text { structural equations modeling technique. We apply this technique to a } \\
\text { sample composed by 153 innovation intensive firms based in Spain. The } \\
\text { findings support the influence of relationship learning and organizational } \\
\text { innovativeness in customer value. }\end{array}$ \\
\hline
\end{tabular}

\section{SCHOLARONE}

Manuscripts 


\title{
GENERATING CUSTOMER VALUE THROUGH THE BOOSTING OF RELATIONSHIPS AND ORGANIZATIONAL INNOVATIVENESS.
}

\begin{abstract}
This study aims to shed light on the question of how companies can generate customer value within the current increasingly dynamic, turbulent and hypercompetitive settings. With this purpose, we intend to examine whether relationship learning mechanisms and organizational innovativeness are actually key drivers of customer value. Concretely, this paper proposes and tests a mediation model that links relationship learning, organizational innovativeness and customer value. In order to test the research model and hypotheses posited in this study, we rely on the use of partial least squares (PLS) pathmodeling, a variance-based structural equations modeling technique. We apply this technique to a sample composed by 153 innovation intensive firms based in Spain. The findings support the influence of relationship learning and organizational innovativeness in customer value.
\end{abstract}

Keywords: relationship learning; organizational innovativeness; customer value, partial least squares

\section{Introduction}

With the aim of remaining competitive and surviving within the current hypercompetitive markets, firms ought to respond steadily to prompt and sudden changes and handle a growing set of snowballing intricacies (Loon, Udin, Hassan, Bakar \& Hanaysha, 2017). Innovative companies might find it easier to cope with these competitive problems by means of developing new or novel products and services more rapidly than their competitors. That is to say, organizational innovativeness enables firms to cope with its increasingly complex setting as one of the key drivers of long-term success within the context of extremely dynamic markets (Baker \& Sinkula, 2002; Acar \& Özşahin, 2018).

According to Vargo and Lusch (2004), innovating entails applying specialized competencies (i.e., knowledge and capabilities) through activities, processes and routines, aimed at the mutual benefit of the actors involved. In this context, firms that truly aim to generate innovations are required to establish and reinforce relationships with their stakeholders. This corporate investment in relationship-based learning mechanisms will lead firms to learn from each other, engender new ideas, and obtain relevant feedback from other groups of interest -i.e., customers, suppliers, competitors, partners, etc.(Leal-Rodríguez, Roldán, Ariza-Montes \& Leal-Millán, 2014). Hence, companies' mutual engagement in sharing information and knowledge with their stakeholders regarding supply chain management activities, market trends, managerial policies or operational issues becomes crucial for fostering innovativeness and attaining in turn superior customer value (Martelo-Landroguez, Barroso-Castro \& Cepeda-Carrión, 2011).

Several studies have assessed the influence of knowledge sharing practices on business performance (Chen \& Stewart, 2010). Others have recognized the need for an efficient management of supply chain relationships and highlight cooperation between 
stakeholders, even between competitors -coopetition- as a strategic issue (Selnes \& Sallis, 2003; Cheung, Myers \& Mentzer, 2011; Salvetat, Géraudel \& d'Armagnac, 2013). However, most of these studies emphasize the assessment of the effects that cooperation and innovation strategies exert on business performance. Besides, there is a scarcity of works addressing the links between relationship building, firm innovativeness and customer value. This paper hence firstly explores the direct impact exerted by relationship learning in the generation of customer value, and secondly, assesses the indirect effect of relationship learning on customer value via organizational innovativeness. Specifically, we attempt to answer the following question: does a firm's involvement in relationship learning mechanisms and innovativeness enhance customer value?

Therefore, this paper brings a substantial contribution to theory and practice, given that it transcends prior-related research and is among the limited research works that aim to examine the links between relationship learning, innovativeness and customer value. To our knowledge, no previous study has joined these links within a conceptual model and has empirically analyzed such relationships. Concretely, this paper posits that companies might be able to boost their competitiveness within the market not only by improving their competence at acquiring external knowledge from their customers via relationship learning mechanisms, but also through their aptitude at reconfiguring and combining this newly acquired external knowledge with its own base of resources and its knowledge base, namely, by fostering its innovativeness. Hence, this study brings new contributions to the literature on knowledge management, innovation and value creation, as the empirical results shed light on the issue of how firms can generate customer value within the current increasingly dynamic, turbulent and hypercompetitive settings. As this question remains uncertain, new empirical insights and reasoning are conveyed in this study jointly with important implications for academics and practitioners.

This study proposes and tests a mediation model. In order to test our research model and hypotheses we rely on the use of partial least squares (PLS) path-modeling, a variancebased structural equations modeling technique. We apply this technique to a sample composed by 153 innovation intensive firms based in Spain. Sectors categorized as innovative shape the population chosen for this study, since these industries might be considered as ideal to carry out this study, given the hypercompetitive markets in which they compete, which demand high doses of flexibility and rapid responses from organizations (Mas-Tur \& Ribeiro-Soriano, 2014)

The following paper is organized as follows. In section 2, we begin with a review of the literature on relationship learning, firm innovativeness and customer value, in order to clarify the definition and measurement of the distinct constructs composing the model. Section 3 brings the methodology followed in this research, comprising the method, measurement scales and data analysis. In fourth place we present the empirical results yielded by PLS analysis, and finally, in section 5 we present the discussion of the results and their main implications jointly with some limitations and suggestions for future research.

\section{Theoretical background}

\subsection{Relationship learning}


According to Ritter (2007), the term "relationship" entails close interactions grounded on shared efforts and mutual agreements. Consistently with the foundations of stakeholder theory (Freeman, 1994), social capital theory (Putnam, 2000) and the relationship view (RV) of the firm, which posit that inter-corporate networks and links are mainly constructed on the basis of stakeholders' reciprocal contributions to shared value generation (Haslam, 2004), this paper brings the concept of relationship learning (RL) into scene. In this study, we principally ground our understanding of RL on the approach proposed by Selnes and Sallis (2003), who were pioneers in its conceptualization as "a joint activity in which two parties strive to create more value together than they would create individually or with other partners" (p. 86). In other words, RL shapes the learning that takes place between the interrelations among partners (Kohtamäki \& Partanen, 2016) For instance, RL mechanisms might occur along supply chains (i.e., interactions between a supplier and its customer), strategic alliances or other kind of partnerships and interfirm relationships. Consequently, corporations are making nowadays huge efforts to build and fulfill partnerships and collaborations with particular allies that may be oriented at bringing mutual benefits to both parts on the basis of long-lasting knowledge-sharing relationships. Consistently with this view, Cheung et al. (2011) shape RL as a multidimensional-second order-construct comprising three dimensions: information sharing, joint sensemaking and knowledge integration. According to Mesquita, Anand and Brush (2008), the combined effect of these three dimensions is expected to exert a noteworthy influence upon the partners' collaboration linkages and therefore enhance their knowledge bases. This concept is also in line with the notion of social capital, described by Rey-Moreno and Medina-Molina (2016) as a relational resource shaped by a wideranging set of features including personal networks, social norms, ethical standards, trust, etc. Several studies posit that social capital might enable RL, suggesting hence that a greater extent of social capital leads to a higher degree of learning within the relationship (Selnes \& Sallis, 2003; Kohtamäki \& Bourlakis, 2012).

Following the approach posited by Selnes and Sallis (2003) and Cheung et al. (2011), the first dimension that determines relationship learning deals with the process of information sharing between two or more entities. This action frequently becomes a starting point and a critical step in the path of creating, strengthening and feeding relationship-based knowledge repositories, which may in turn lead them to become more operationally efficient. The second component of the RL construct is joint sensemaking. Generally, the actors involved in the business relationship might present difference with regard to the ways in which they grasp and perceive the same information (i.e. sensemaking), or possibly do not possess the knowledge compulsory to make sense of it. Therefore, according to Leal-Rodríguez et al., (2014), firms should also apply a range of mechanisms aimed at boosting joint sensemaking (i.e., carrying out face to face meetings throughout visit programs, strengthening informal or personal networks, and developing projectbased and/ or cross-functional teams). This array of instruments may help companies to solve some of the problems inherent to relationship-based learning and to develop their cooperative network, crafting hence joint learning areas, similar to the concept of "Ba" proposed by Nonaka and Konno (1998). Finally, knowledge integration is proposed as the third dimension of relationship learning. The different partners that compose the network largely develop relationship-based organizational memories or repositories that help them to store the relationship-specific gained knowledge. Such knowledge is meant to be internally disseminated across the firm and transformed into explicit data files and reports (Selnes \& Sallis, 2003; Leal-Rodríguez et al., 2014). 


\subsection{Organizational innovativeness}

Organizational innovativeness (OI) is broadly assumed to play a crucial role as for the consecution of competitive advantages and the enhancement of organizational performance. Nevertheless, this topic transcends the managerial literature and is encompassed by a widespread variety of scientific currents (i.e., psychology, marketing, communication, anthropology, sociology, engineering, etc.) (Johannessen, Olsen \& Lumpkin, 2001). Curiously, OI is among the most critical factors in terms of its impact on organizational performance, yet management literature has emphasized the analysis of innovation outcomes and has rather disregarded innovativeness (a firm-level driver of innovation outcomes), leading to a comparatively under-researched topic (Klimas \& Czakon, 2018).

It is perhaps due to the immense volume of studies regarding innovation and to the multilayered nature of this topic that there is certain incongruence and a lack of precision with regard to its conceptual delimitation. Hence, it seems suitable to provide a succinct review or summarize of the key literature on organizational innovativeness with the purpose of delimiting its meaning, while particularly applied to the managerial field. If we attend to the etymological origin of the innovation term, it derives from Latin - "innovare"-, which implies the alteration of something by means of the insertion of a certain novelty. Damanpour (1991) explains innovation as the elaboration and improvement of new products, services or processes. Consistent with Porter (1990), innovating entails discovering new ways of doing what is actually commercialized. It is clear that the innovation process requires hence from the complementary stages of invention and commercialization. Therefore, we understand organizational innovativeness as the firm's quality of being innovative and its remarked endeavor in the process of generating and applying innovative ideas, products, services, processes and methods successfully (Hurley \& Hult, 1998).

At this point, it is wise and pertinent to clarify the distinction between innovation and innovativeness. On the one hand, innovation can be broadly labelled as the firm's involvement and development of new or novel methods and technologies while performing their business activity (Loon et al., 2017). Following these authors, innovation might be regarded as any practice that is in its essence new or novel to the firm (i.e., new products or services, new equipment, new processes, new policies, new projects, and new knowledge that are in a more direct or indirect manner linked to its work routines). On the other hand, innovativeness comprises the organization's willingness and predisposition to apply and recombine the existing resources and knowledge base into valuable prospects that might drive competitive success to the firm (Loon et al., 2017; Acar \& Özşahin, 2018). Moreover, in line with Jardon (2018), OI can be considered a dynamic capability that joins a combination of cultural features, processes, resources, and capabilities focused on innovation.

There can be observed some controversy in the literature regarding the actual conceptualization of firm innovativeness: on the one hand, some scholars believe that innovation appears immediately after some novelty or new idea regarding the firm's products, services or processes has been introduced (Zaltman, Duncan \& Holbeck, 1973; Damanpour \& Gopalakrishnan, 1998). On the other hand, several authors that consider that in order to reach innovation, it is not sufficient to produce such novelty or new idea, but it becomes fundamental to being able to successfully grow and apply this idea to 
commercial purposes (Nelson, 1968; Escorsa \& Valls, 1997). Therefore, while the first group pinpoints innovation within the initial step, the latter only sets it at the implementation phase.

\subsection{Customer value}

The notion of customer orientation is described by Narver and Slater (1990) as companies' enhanced grasp of their costumers' needs and requests for endless superior value creation (Acar \& Özşahin, 2018). Namely, this concept reflects the firm's purposive emphasis on satisfying customer needs. Hence, the firm's capability to recognize what the client values in its specific offer of products or services, jointly with the subsequent ability to create value for them and its management over time has been extensively acknowledged as a central feature of corporate strategy (Drucker, 1985; Porter, 1998; Slater \& Narver, 1998).

Thus, what is exactly meant by value? Kumar and Reinartz (2016, p. 37) define perceived value as "customers' net valuation of the perceived benefits accrued from an offering that is based on the costs they are willing to give up for the needs they are seeking to satisfy". Accordingly, these authors posit that perceived customer value of an offering encompasses the accumulation of paybacks expected or experienced by the client jointly with the costs inherent to them. Therefore, the fundamental characteristic of this conceptualization deals with customers' choices that, ceteris paribus, make the most of the wanted consequences or benefits and reduce coexisting concomitant undesired consequences or costs (Kumar \& Reinartz, 2016). Similarly, Rihova, Buhalis, Moital and Gouthro (2015) view customer value as the customers' individual appraisal of the compensation between the benefits they obtain and the costs or sacrifices in which they incur.

Defining what the clients expect from the products or services they demand enables the organization's formulation of its value proposal (Martelo-Landroguez, Barroso-Castro \& Cepeda-Carrión, 2013). Hence, the attainment of competitive advantages is highly dependent on the firm's proficiency at generating such level of value for their clients whose return surpasses the cost inherent to its creation (DeSarbo, Jedidi \& Sinha, 2001). Customer value has lately arisen as a topic of increasing interest both at the managerial and academic spheres, since it is considered a critical source of competitive advantage, the main foundation of marketing strategies, a key strategic instrument for attracting and retaining customers and a proper predictor of customers' repurchasing purposes (Spiteri \& Dion, 2004; Martelo-Landroguez et al., 2013). The current hypercompetitive global business environment has led to managers' increased awareness and focus on the generation of superior customer value (Smith \& Colgate, 2007), which has partly come to substitute some rather incomplete concepts such as quality service or customer satisfaction (Martelo-Landroguez et al., 2013).

More recently, along with authors like Prahalad and Ramaswamy (2004) and Vargo and Lusch (2008), the notion of customer value has evolved towards the more advanced concept of value co-creation. According to these authors, customer value creation involves the process whereby companies and customer, as peers, create value jointly both for themselves and for each other (Zhang, Guo, Hu \& Liu, 2017). By virtue of such cocreation process, both subjects develop personalized joint involvements through ongoing dialogue and exchanges (Grönroos, 2008; Zhang et al., 2017). 


\subsection{The link between relationship learning and customer value.}

Bearing in mind the current social-economic setting, where companies are required to work closely to their customers, suppliers and other partners, it becomes critical that they are able and certainly willing to be consciously sharing information and knowledge with them. Such knowledge interchange may lead both parts to be reciprocally augmenting their knowledge repositories and capabilities that might in turn serve them to strengthen and develop their innovative process (Leal-Millán, Roldán, Leal-Rodríguez \& OrtegaGutiérrez, 2016). With this regard, Hillman \& Keim, (2001, p. 127) state that "managing relationships with primary stakeholders $[. .$.$] can result in much more than just their$ continued participation in the firm. Effective stakeholder management-relations with primary stakeholders [...] can constitute intangible, socially complex resources that may enhance firms' ability to outperform competitors in terms of long-term value creation".

Nowadays, customers' expertise and insights may substantially affect the process of value creation (Cossío-Silva, Revilla-Camacho, Vega-Vázquez \& Palacios-Florencio, 2016). Hence, value should currently be regarded as a joint function of the actions of customers and the firm and that frequently derives from co-creation (Vargo \& Lusch, 2008). Consequently, firms are nowadays encouraged to get involved in cooperative learning activities if they wish to remain competitive within a business context characterized by technological shifts and growing international competition (Chen, Lin \& Chang, 2009). Organizations may enlarge their knowledge base by learning from one another as a result of their engagement in relationship learning processes with their suppliers, partners, and customers, etc. (Leal-Millán et al., 2016). Thereby, companies might cultivate and uphold the learning competence of targeted customer-supplier ties. Yet, relationship learning cannot be commanded by whichever organization, nonetheless is dependent on both parties' eagerness in such cooperative learning process (Selnes \& Sallis, 2003). This is certainly in line with what Yang and Lai (2012) argue in their study on the link between $\mathrm{RL}$ and relational knowledge stores. These authors sustain that partners' willingness to share, infer, assimilate and store information and knowledge into relationship memories will lead both parts to a better mutual comprehension of partners needs and circumstances, to the creation of enhanced interrelationships, and to the enlargement of competitive advantage across the supply chain. In this vein, following Kohtamäki and Partanen (2016), a distinguishing feature of joint value creation is that it often takes place in the context of ongoing customer-supplier interactions.

Therefore, any firm that aims to remain competitive should in some manner or another take their customers into consideration and may hence attempt to learn as much as possible from them in order to bring together into the market an array of products or services that may lead to the maximization of customer value (Cepeda-Carrión, MarteloLandroguez, Leal-Rodríguez \& Leal-Millán, 2017). In this line, Cegarra-Navarro, Jiménez-Jiménez \& Fernández-Gil (2014, p. 311) state that "the acquisition of knowledge about the customer, the fostering of long-term relationships and the sharing of activities creates value through the creation of trust, reputation and an ability to better respond to present and future customer needs". Consistently with the knowledge-based view (KBV) of the firm, knowledge is assumed a fundamental driver of value creation. Bearing in mind that knowledge management comprises a firm's capability to gather, combine and apply knowledge from diverse sources with the aim of transforming tangible resources into value in the form of innovative products or services (Kiessling, Richey, Meng \& 
Dabic, 2009), a firm's relationships with its distinct partners should be taken into account as one of those critical sources of organizational knowledge. Thus, we hypothesize (Figure 1):

\section{H1: relationship learning is positively related to customer value.}

2.5. The mediating role of organizational innovativeness in the RL-CV link.

Consistently with the resource-based view, there exist four indicators to measure a company's prospective to attain sustainable competitive advantages -value, peculiarity, difficult to imitate, and difficult to substitute-. If a firm gathers cherished and unusual resources, it might combine them into the development of innovative and highly valuable products and services, which cannot be easily replicated by competitors, leading the firm to competitive advantages achievement (Barney, 1991). In this line, Porter (1990) regards innovation as the cornerstone of long-term sustainable competitive advantage attainment (Acar \& Özșahin, 2018). Subsequently, studies bringing empirical evidence of the existence of a positive link between OI and organizational performance have profusely appeared (Zhou, Yim \& Tse, 2005; Lin, Peng \& Kao 2008; Leal-Rodríguez, Eldridge, Roldán, Leal-Millán \& Ortega-Gutiérrez, 2015).

With this regard, it seems likely that increasing the amount of knowledge that a firm possesses about their clients leads them to design and provide increasingly accurate and appreciated products and services for its clients. Similarly, customers that increase their knowledge about their suppliers are more likely to make better choices with regard to the satisfaction of their own needs and requests (von Hippel, 1994). To develop and launch innovative products and services, organizations might obtain highly valuable knowledge from their different allies, clients and suppliers throughout their immersion in relationship learning mechanisms. Besides, prior works have spotted at the positive link between organizational learning and innovation outcomes (Baker \& Sinkula, 2007; GarcíaMorales, Ruiz-Moreno \& Llorens-Montes, 2007). Interestingly, some authors state that organizational learning, namely, the process underlying companies' attainment and assimilation of new external knowledge (Jimenez-Jimenez \& Sanz-Valle, 2011), shapes the fundamental driver of the firm's adaptability and innovativeness (Peris-Ortiz, DeveceCarañana \& Navarro-Garcia, 2018).

In line with Cepeda-Carrión et al. (2017), based on the knowledge-based view of the firm, both knowledge and innovativeness might be regarded as key drivers of value creation. In this vein, OI, namely the firm's capacity to innovate is narrowly linked to what Cohen and Levinthal (1990) called absorptive capacity, meaning that organizations that combine their own knowledge base with externally absorbed related knowledge will develop a higher capacity to innovate, and will reach in turn competitive advantage (Hurley \& Hult, 1998). Therefore, firms should strengthen their ability to learn from and anticipate customers' needs since the current competitive scenario requires a quick response from firms in order to maintain their clients and capture new ones, thus beating their competitors. This way, learning from the customers stands as a critical to instrument to increase customer value, as well as a fundamental step while developing innovation. Hence, we posit the following hypothesis (Figure 1): 
H2: organizational innovativeness positively mediates the link between relationship learning and customer value.

\section{-INSERT FIGURE 1 ABOUT HERE-}

\section{Method}

\subsection{Sample and data collection}

The empirical base for this study grounds in survey data. This research is carried out at the company level and the selected population are innovative sectors based in Spain. Both researchers and professional experts label this industry as hypercompetitive, demanding high doses of flexibility, adaptability and rapid responses from firms. This study chooses the sector based on the classification provided by the Spanish National Institute of Statistics (Cotec, 2009) of high and medium-high technology industries, which yields a population of 2,360 companies. The instrument used to collect the data was an off-line survey. Since we chose the firm as the level of analysis, senior managers were the respondents of the survey. After a single mailing effort, we obtained a total of 153 usable surveys, which supposes a response rate of $6.48 \%$. The decision to choose this sector roots on the fact that these firms emphasize the importance of customer value, being required to continually adapt to clients' requests and specificities if they wish to remain competitive.

\subsection{Measures}

All the constructs considered in this research are measured by means of the use of questionnaire items derived from priorly used and validated scales (Table 1). The authors implemented some adjustments required to adapt to the particular research context (i.e., translating the items to Spanish language and particular business context). Thus, we conducted in advance a pilot test of the questionnaire to evaluate its content validity. Seventeen items were used to measure the RL construct, as a superordinate second order composite construct, adapting to this aim the scale proposed by Selnes and Sallis (2003). While attempting to measure the organizational innovativeness construct this study adapts the four items scale used by Hurley and Hult (1998). We measured the customer value variable through the use of the three items scale proposed by Rust, Zeithaml and Lemon (2001). Finally, except for the control variables -firm's size (amount of employees) and seniority (number of years since its establishment)- the rest of the variables are measured through a seven-point Likert type scale.

\section{-INSERT TABLE 1 ABOUT HERE-}

\subsection{Data Analysis}

The research model and hypotheses posited in this study are examined through the application of partial least squares (PLS) path-modeling, a variance-based structural equation modeling technique (Roldán \& Sánchez-Franco, 2012). PLS allows the evaluation of the reliability and validity of the constructs' theoretical measures measurement or outer model- together with the estimation of the relationships posited 
between constructs -structural or inner model- (Barroso, Cepeda-Carrión \& Roldán, 2010). PLS is a tool of great interest and broad applicability while aiming to assess complex linkages involving a wide diversity of latent variables (i.e., unobservable constructs) and manifest variables (i.e., items or indicators), comprising both direct, mediated or moderated relationships (Hair, Hult, Ringle \& Sarstedt, 2016; Hair, Sarstedt, Ringle \& Gudergan, 2017).

PLS is a suitable methodology for developing research within the social sciences field due to the following reasons: (i) the constructs that conform our research model are composites. The usage of PLS when a composite measurement model is supported has been endorsed both theoretically and empirically (Rigdon, 2012; Sarstedt, Hair, Ringle, Thiele \& Gudergan, 2016); (ii) scales are often barely developed; (iii) data tend to be nonnormally distributed; and (iv) the focus is typically more on predicting dependent variables than in confirmatory purposes or global fit of the model (Roldán \& SánchezFranco, 2012). This paper applies the SmartPLS 3.2.7 software to test the validity and statistical significance of the measurement and structural model correspondingly (Ringle, Wende \& Becker, 2015).

\section{Results}

PLS models assessment encompasses two main steps: (i) corroborating the reliability/validity of the measurement model and (ii) examining the sign and significance of the relationships -paths- comprised at the structural model.

\subsection{Measurement model}

The analysis of the measurement model depicts satisfactory outcomes. In first place, all the indicators satisfy the requisite of individual item reliability, since the outer loadings are, in general, greater than 0.707 (Table 2). Only a few items were removed since their outer loadings were too low. Second, all the constructs meet the requirement of construct reliability, given that their composite reliabilities and Dijkstra-Henseler's indicator (Rho_A) values are over the 0.7 threshold (Table 3). Third, the latent variables comprising the conceptual model reach convergent validity, since their average variance extracted (AVE) values surpass the 0.5 critical level (Table 3). Lastly, Table 3 reveals that all the constructs under assessment attain discriminant validity accordingly with both the Fornell-Larcker and the HTMT criteria (Henseler, Ringle, \& Sarstedt, 2015).

\section{-INSERT TABLE 2 ABOUT HERE-}

-INSERT TABLE 3 ABOUT HERE-

\subsection{Structural model}

Following Hair, Sarstedt, Hopkins and Kuppelwieser (2014), this paper employs a bootstrapping technique (5000 re-samples) to generate standard errors and t-statistics that enable the evaluation of the statistical significance for the links comprised within the two research models under consideration. Table 4 contains the main parameters obtained for the structural models under study. The coefficient of determination $\left(R^{2}\right)$ is assumed to be 
the main criterion for the explained variance, which is shown in the dependent construct. In Model 1, CV attains a $\mathrm{R}^{2}$ value of 0.245 , whereas in Model 2, CV reaches a $\mathrm{R}^{2}$ value of 0.270 and OI reaches a $R^{2}$ value of 0.197 (Table 4). These results ratify that the structural model has adequate predictive relevance for the endogenous constructs organizational innovativeness and customer value-

Table 4 includes the direct (Model 1) and indirect (Model 2) relationships hypothesized between RL, OI and CV. As shown by Figure 2, all the direct links hypothesized -a, b and c'-are significant. This constitutes a necessary but not a sufficient condition, for the existence of an indirect effect of RL on CV via OI (Preacher \& Hayes, 2008). Hence, this paper follows the methodological approach suggested by Preacher and Hayes (2008) and Taylor, MacKinnon and Tein (2008) to verify the actual existence of a mediation hypothesis. Our model also depicts satisfactory results for the indirect effect. Following Williams and MacKinnon (2008), we applied a bootstrapping technique to test the mediation effect. To this aim, Chin (2010) suggests to use the model in question including both direct and indirect paths, performing N-bootstrap resampling and ultimately multiplying the direct paths that encompass the indirect path under assessment. The 5,000 resamples also generate $95 \%$ bias corrected confidence intervals (percentile) for the mediator, as shown in Table 4 (Leal-Rodríguez et al., 2015).

-INSERT TABLE 4 ABOUT HERE-

\section{-INSERT FIGURE 2 ABOUT HERE-}

\section{Discussion and conclusions}

This paper is aimed at assessing the effects of firms' endeavors on relationship learning and organizational innovativeness on customer value, which shapes a topic that has been scarcely studies in the literature. To this end it empirically assesses whether the RL-CV, RL-OI and OI-CV direct links are positive and significant. Additionally, it examines whether OI mediates the link between RL and CV. Our results are summarized as follows: both the direct and indirect relationships posited within the research model are positive and significant, providing hence empirical evidence to sustain the two research hypotheses under assessment.

Thus, our empirical results are in line with the assumptions that underlie the research hypotheses, suggesting that the firms' endeavors in deploying RL mechanisms and OI are key drivers of CV. These results are in accordance with the service-dominant logic theory. Following Vargo and Lusch (2004), the service-dominant logic entails a shift in business' priorities that leads firms to set its interest on customizing their offerings, acknowledging that customers might become co-producers, and to struggle to make the most of customers' engagement in the process of customization to better fit their particular needs. The service-dominant logic is thus characterized by actively involving clients within the process of product or service specialization and value creation. In this vein, Prahalad and Ramaswamy (2004) stress the importance of the customer-firm interaction by stating that "eventually, the roles of the company and the consumer converge toward a unique cocreation experience" (p. 6). Therefore, if companies concentrate on their core competencies, they must build and cultivate collaborative networks and externalize 
essential knowledge and competencies to the network. This entails that companies must become coopetitive -concurrently competitive and cooperative- (Day 1994), and need to learn how to manage their interrelationships with customers.

Various works have assessed the need for an efficient management of customers' knowledge and highlight customers' involvement as a strategic issue (Cheung et al., 2011). Most of this research emphasizes the analysis of the effects that cooperative networks and innovation strategies exert upon business performance. Nevertheless, there is a lack of empirical works focused at assessing the links between relationship learning, organizational innovativeness and customer value. Moreover, there is a broad range of studies that address cooperative strategies and innovativeness within manufacturing firms and fewer studies conducted in service industries. Concretely, the study of these issues in professional services firms or consultancy companies remains scarcely assessed within the literature on OI.

Hence, this research firstly attempts to unveil whether relationship learning and organizational innovativeness could be actually considered critical drivers of customer value. To this aim, this paper models the direct effect exerted by relationship learning in the creation of customer value, and secondly, introduces the indirect effect of relationship learning on customer value via organizational innovativeness. Results from the PLS empirical analysis reveal that all the direct relationships hypothesized are positive and significant (Table 4). First, we find support for the first hypothesis (H1), which links relationship learning and customer value. Second, our results find evidence to sustain the mediation hypothesis $(\mathrm{H} 2)$, which states that relationship learning indirectly affects customer value via organizational innovativeness. Our findings are in line with those of prior-related studies, such as the one developed by Roxas, Battisti and Deakins (2014), which focuses on examining the links between managerial learning, innovation and firm performance in SMEs.

In conclusion, this study brings both theoretical implications. First, while there are precedents in the specialized academic literature that link customer relationship management (CRM) and innovation capability (Lin, Chen \& Kuan-Shun Chiu, 2010) or CRM practices with customers' satisfaction and loyalty (Das \& Mishra, 2019; Saleh \& El Saheli, 2018), this paper is among the limited research works that attempt to explain the links between relationship learning, innovativeness and customer value. To our knowledge, no previous study has combined RL, OI and CV in a conceptual model and has empirically tested these relationships. Thus, transcending prior research, this paper develops a theoretical model that examines the role exerted by two drivers of customer value. Concretely, this study highlights the significant role played by relationship learning mechanisms on the maximization of customer value and the mediating role of organizational innovativeness on the RL-CV link. Secondly, we propose that firms might enhance their competitiveness within the market not only by improving their competence at acquiring external knowledge from their customers via RL mechanisms, but also by virtue of their ability to reconfigure and combine this external knowledge with its own resources and knowledge base, leading to the fostering of its OI capability. Thus, this study contributes to the existing body of research, by providing deeper explanations of the mechanisms underlying the maximization of customer value. 
This research work also reveals a series of managerial implications that are worth highlighting. The main findings of this work may offer managers some insights regarding the path to follow in order to be more competitive. Hence, this research suggests that the effective management and optimization of customers' knowledge and its further integration within the firm's innovative process is the direction to follow for firms aimed at enhancing customer value. This conclusion is especially noteworthy in the context of innovation intensive firms, which are required to offer extremely customized services to their clients. In this vein, firms that share information and knowledge with their customers and integrate these external insights into its own knowledge repository, will find it easier to develop innovative offers that better fit customers' wishes, leading to better results in terms of customers' acquisition and retention, customers' loyalty and customers' satisfaction. Our results are consistent with prior-related works such as the one developed by Dekoulou and Trivellas (2017), who argue that firms should enable structures aimed at supporting the development of competitive advantages based on innovation, creativity and business clients' relationships. In light of the empirical results derived from this study, we would recommend managers in first place, to reinforce their information sharing mechanisms with customers in order to exchange information regarding: products and services characteristics, customers' satisfaction with such products and services, changes in customers' needs and preferences, changes in the technology of focal products, unexpected problems that may arise, strategic shifts and changes in corporate policies, among other topics. Secondly, we urge practitioners not to limit themselves to the mere exchange of information, but to build joint sensemaking arenas so that they can more steadily adjust the firm's and customers' common understanding of the different issues affecting their relationship. In this vein, it is especially advisable to establish joint teams to solve operational problems, to promote face-to-face interactions in order to refresh the personal network and smooth communication, and to periodically examine and update the storage of such shared information into corporate databases. In third place, given the relevance of OI, firms should emphasize the active seek of innovative ideas, as well as the acceptance of product and process innovations that are derived from R\&D efforts. Besides, employees should be encouraged to develop new ideas, by providing incentives, removing obstacles to creativity and avoiding failure penalizations. Finally, based on the verification of the mediation hypothesis, we would suggest managers to focus on finding externally that specific knowledge that might lead them to develop innovations that are valued by customers.

The outcomes of this paper should be understood in light of its underlying context and inherent limitations. First, it should be acknowledged that we only rely on managers' perceptions, failing to have data from other collectives within the firm. Second, this study only considers firms operating in a specific geographical context (Spain). Thus, scholars should be cautious while generalizing these outcomes to distinct settings. Third, although we provide evidence of causality, causality itself has not been proven, since following Fornell and Larcker (1981), causal relationships cannot be proven, but are always presumed by the researcher, who posits its direction. Concerning further research lines, we aim to extend our research model by incorporating the concept of "relationship memory", defined by Cegarra-Navarro et al., (2014, p. 310) as "a shared memory that develops idiosyncratic routines in the form of encoded formal and informal procedures and scripts for how parties have learned to do things". Perhaps this construct may exert an influence -direct or indirect- in the transition from knowledge acquisition to innovation generation that might be interesting to explore. Another particularly intriguing path to explore is, as proposed by Vargo and Lusch (2008), the enlargement of conceptual 
foundations of organizational innovativeness and performance enhancement, under the framework of value co-creation and cooperative networks. There is still much to unveil concerning how service firms actually innovate and adapt to the increasingly demanding and better-informed clients that are proliferating these days.

\section{References}

Acar, A. Z., \& Özşahin, M. (2018). The relationship among strategic orientations, organizational innovativeness, and business performance. International Journal of Innovation Management, 22(01), 1850009.

Baker, W. E., \& Sinkula, J. M. (2002). Market orientation, learning orientation and product innovation: delving into the organization's black box. Journal of Market-focused Management, 5(1), 5-23.

Baker, W. E., \& Sinkula, J. M. (2007). Does market orientation facilitate balanced innovation programs? An organizational learning perspective. Journal of Product Innovation Management, 24(4), 316-334.

Barney, J. (1991). Firm resources and sustained competitive advantage. Journal of Management, 17(1), 99-120.

Barroso, C., Cepeda-Carrión, G., \& Roldán, J. L. (2010). Applying maximum likelihood and PLS on different sample sizes: studies on SERVQUAL model and employee behavior model. In Handbook of Partial Least Squares (pp. 427-447). Springer Berlin Heidelberg.

Cegarra-Navarro, J. G., Jiménez-Jiménez, D., \& Fernández-Gil, J. R. (2014). Improving customer capital through relationship memory at a commercial bank in Spain. Knowledge Management Research \& Practice, 12(3), 310-321.

Cepeda-Carrión, I., Martelo-Landroguez, S., Leal-Rodríguez, A. L., \& Leal-Millán, A. (2017). Critical processes of knowledge management: An approach toward the creation of customer value. European Research on Management and Business Economics, 23(1), $1-7$.

Chen, L., \& Stewart, R. A. (2010). The moderating effect of knowledge sharing on the relationship between manufacturing activities and business performance. Knowledge Management Research \& Practice, 8(4), 285-306.

Chen, Y. S., Lin, M. J. J., \& Chang, C. H. (2009). The positive effects of relationship learning and absorptive capacity on innovation performance and competitive advantage in industrial markets. Industrial Marketing Management, 38(2), 152-158.

Cheung, M. S., Myers, M. B., \& Mentzer, J. T. (2011). The value of relational learning in global buyer - supplier exchanges: a dyadic perspective and test of the pie - sharing premise. Strategic Management Journal, 32(10), 1061-1082. 
Chin, W. W. (2010). Bootstrap cross-validation indices for PLS path model assessment. In Handbook of Partial Least Squares (pp. 83-97). Springer Berlin Heidelberg.

Cohen, W. M., \& Levinthal, D. A. (1990). Absorptive capacity: A new perspective on learning and innovation. Administrative Science Quarterly, 35(1) 128-152.

Cossío-Silva, F. J., Revilla-Camacho, M. Á., Vega-Vázquez, M., \& Palacios-Florencio, B. (2016). Value co-creation and customer loyalty. Journal of Business Research, 69(5), 1621-1625.

Cotect (2009). Tecnología e innovación en España. Informe COTEC 2009; Fundación Cotec: Madrid, Spain, 2009.

Damanpour, F. (1991). Organizational innovation: a meta-analysis of effects of determinants and moderators. Academy of Management Journal, 34(3), 555-590.

Damanpour, F., \& Gopalakrishnan, S. (1998). Theories of organizational structure and innovation adoption: the role of environmental change. Journal of Engineering and Technology Management, 15(1), 1-24.

Das, S., \& Mishra, M. (2019). The Impact of Customer Relationship Management (CRM) Practices on Customer Satisfaction. In Business Governance and Society (pp. 43-54). Palgrave Macmillan, Cham.

Day, G. S. (1994). The capabilities of market-driven organizations. The Journal of Marketing, 58(4), 37-52.

Dekoulou, P., \& Trivellas, P. (2017). Organizational structure, innovation performance and customer relationship value in the Greek advertising and media industry. Journal of Business \& Industrial Marketing, 32(3), 385-397.

DeSarbo, W. S., Jedidi, K. \& Sinha, I. (2001). Customer value analysis in a heterogeneous market", Strategic Management Journal, 22(9), 845-857.

Drucker, P. (1985). Innovation and Entrepreneurship. New York: Harper \& Row.

Escorsa, P., \& Valls, J. (1997). Tecnología e innovación en la empresa. Dirección y Gestión. Ediciones UPC, Barcelona.

Fornell, C., \& Larcker, D. F. (1981). Evaluating structural equation models with unobservable variables and measurement error. Journal of Marketing Research, 18(1), 39-50.

Freeman, R. E. (1994). The politics of stakeholder theory: Some future directions. Business Ethics Quarterly, 4(4), 409-421.

García-Morales, V. J., Ruiz-Moreno, A., \& Llorens-Montes, F. J. (2007). Effects of technology absorptive capacity and technology proactivity on organizational learning, innovation and performance: An empirical examination. Technology Analysis \& Strategic Management, 19(4), 527-558. 
Grönroos, C. (2008). Service logic revisited: who creates value? And who cocreates?. European Business Review, 20(4), 298-314.

Hair Jr, J. F., Hult, G. T. M., Ringle, C., \& Sarstedt, M. (2016). A Primer on Partial Least Squares Structural Equation Modeling (PLS-SEM). Sage publications.

Hair Jr, J. F., Sarstedt, M., Ringle, C. M., \& Gudergan, S. P. (2017). Advanced Issues in Partial Least Squares Structural Equation Modeling. Sage Publications.

Hair Jr, J., Sarstedt, M., Hopkins, L., \& G. Kuppelwieser, V. (2014). Partial least squares structural equation modeling (PLS-SEM) An emerging tool in business research. European Business Review, 26(2), 106-121.

Haslam, N. (2004). Relational models theory: A contemporary overview (pp. 3-25). Laurence Erlbaum Associates. Mahwah, NJ.

Henseler, J., Ringle, C. M., \& Sarstedt, M. (2015). A new criterion for assessing discriminant validity in variance-based structural equation modeling. Journal of the Academy of Marketing Science, 43(1), 115-135.

Hillman A. J., \& Keim, G. D. (2001). Shareholders and social issue. Strategic Management Journal, 2(2), 125-139.

Hurley, R. E., \& Hult, G. T. M. (1998). Innovation, market orientation and organizational learning: an integration and empirical examination, Journal of Marketing, 62(3), 42-54.

Jardon, C. M. (2018). Moderating effect of intellectual capital on innovativeness in Latin American subsistence small businesses. Knowledge Management Research \& Practice, 16(1), 134-143.

Jiménez-Jiménez, D., \& Sanz-Valle, R. (2011). Innovation, organizational learning, and performance. Journal of Business Research, 64(4), 408-417.

Johannessen, J. A., Olsen, B., Lumpkin, G. T. (2001). Innovation as newness: what is new, how new, and new to whom? European Journal of innovation management, 4(1), 20-31.

Kiessling, T. S., Richey, R. G., Meng, J., \& Dabic, M. (2009). Exploring knowledge management to organizational performance outcomes in a transitional economy. Journal of world business, 44(4), 421-433.

Klimas, P., \& Czakon, W. (2018). Organizational innovativeness and coopetition: a study of video game developers. Review of Managerial Science, 12(2), 469-497.

Kline, R. B. (2015). Principles and practice of structural equation modeling. Guilford publications. 
Kohtamäki, M., \& Bourlakis, M. (2012). Antecedents of relationship learning in supplier partnerships from the perspective of an industrial customer: the direct effects model. Journal of Business \& Industrial Marketing, 27(4), 299-310.

Kohtamäki, M., \& Partanen, J. (2016). Co-creating value from knowledge-intensive business services in manufacturing firms: The moderating role of relationship learning in supplier-customer interactions. Journal of Business Research, 69(7), 2498-2506.

Kumar, V., \& Reinartz, W. (2016). Creating enduring customer value. Journal of Marketing, 80(6), 36-68.

Leal-Millán, A., Roldán, J. L., Leal-Rodríguez, A. L., \& Ortega-Gutiérrez, J. (2016). IT and relationship learning in networks as drivers of green innovation and customer capital: Evidence from the automobile sector. Journal of Knowledge Management, 20(3), 444464.

Leal-Rodríguez, A. L., Eldridge, S., Roldán, J. L., Leal-Millán, A. G., \& OrtegaGutiérrez, J. (2015). Organizational unlearning, innovation outcomes, and performance: The moderating effect of firm size. Journal of Business Research, 68(4), 803-809.

Leal-Rodríguez, A. L., Roldán, J. L., Ariza-Montes, J. A., \& Leal-Millán, A. (2014). From potential absorptive capacity to innovation outcomes in project teams: The conditional mediating role of the realized absorptive capacity in a relational learning context. International Journal of Project Management, 32(6), 894-907.

Lin, C. H., Peng, C. H., \& Kao, D. T. (2008). The innovativeness effect of market orientation and learning orientation on business performance. International Journal of Manpower, 29(8), 752-772.

Lin, R. J., Chen, R. H., \& Kuan-Shun Chiu, K. (2010). Customer relationship management and innovation capability: an empirical study. Industrial Management \& Data Systems, 110(1), 111-133.

Loon, L. K., Udin, Z. M., Hassan, M. G., Bakar, Z. A., \& Hanaysha, J. R. (2017). The Power of Organizational Innovativeness in Shaping Supply Chain Operational Performance. Advanced Science Letters, 23(9), 8579-8585.

Martelo-Landroguez, S., Barroso-Castro, C., \& Cepeda-Carrión, G. (2011). Creating dynamic capabilities to increase customer value. Management Decision, 49(7), 11411159.

Martelo-Landroguez, S., Barroso-Castro, C., \& Cepeda-Carrión, G. (2013). Developing an integrated vision of customer value. Journal of Services Marketing, 27(3), 234-244.

Mas-Tur A, \& Ribeiro-Soriano, D. (2014). The level of innovation among young innovative companies: the impacts of knowledge-intensive services use, firm characteristics and the entrepreneur attributes. Service Business, 8(1), 51-63. 
Mesquita, L. F., Anand, J., \& Brush, T. H. (2008), Comparing the resource-based and relational views: knowledge transfer and spillover in vertical alliances. Strategic Management Journal, 29(9), 913-941.

Narver, J. C., \& Slater, S. F. (1990). The effect of a market orientation on business profitability. Journal of Marketing, 54(4), 20-35.

Nelson, R. R. (1968). A diffusion model of international productivity differences in manufacturing. American Economic Review, 58(5), 1219-1248.

Nonaka, I., \& Konno, N. (1998). The concept of "Ba": Building a foundation for knowledge creation. California Management Review, 40(3), 40-54.

Peris-Ortiz, M., Devece-Carañana, C. A., \& Navarro-Garcia, A. (2018). Organizational learning capability and open innovation. Management Decision, 56(6), 1217-1231.

Porter, M. E. (1990). The Competitive Advantage Of Nations. Ed. Macmillan, London. Porter, M. E. (1998), Competitive Advantage: Creating and Sustaining Superior Performance, Free Press, New York, NY.

Prahalad, C. K., \& Ramaswamy, V. (2004). Co-creating unique value with customers. Strategy \& Leadership, 32(3), 4-9.

Preacher, K. J., \& Hayes, A. F. (2008). Asymptotic and resampling strategies for assessing and comparing indirect effects in multiple mediator models. Behavior Research Methods, 40(3), 879-891.

Putnam, R. D. (2000). Bowling alone: America's declining social capital. In Culture and politics (pp. 223-234). Palgrave Macmillan, New York.

Rey-Moreno, M., \& Medina-Molina, C. (2016). Omnichannel strategy and the distribution of public services in Spain. Journal of Innovation \& Knowledge, 1(1), 36-43.

Rigdon, E. E. (2012). Rethinking partial least squares path modeling: In praise of simple methods. Long Range Planning, 45(5-6), 341-358.

Rihova, I., Buhalis, D., Moital, M., \& Gouthro, M. B. (2015). Conceptualising customer-to-customer value co-creation in tourism. International Journal of Tourism Research, 17(4), 356-363.

Ringle, C. M., Wende, S., \& Becker, J. M. (2015). SmartPLS 3. Bönningstedt: SmartPLS.

Ritter, T. (2007). A framework for analyzing relationship governance. Journal of Business \& Industrial Marketing, 22(3), 196-201.

Roldán, J. L., \& Sánchez-Franco, M. J. (2012). Variance-based structural equation modeling: guidelines for using partial least squares. Research methodologies, innovations and philosophies in software systems engineering and information systems, 193. 
Roxas, B., Battisti, M., \& Deakins, D. (2014). Learning, innovation and firm performance: knowledge management in small firms. Knowledge Management Research \& Practice, 12(4), 443-453.

Rust, R. T., Zeithaml, V. A., \& Lemon, K. N. (2001). Driving customer equity: How customer lifetime value is reshaping corporate strategy. New York: The Free Press.

Saleh, L., \& El Saheli, L. (2018). The Impact of CRM Strategy on Customer Loyalty in SMEs. International Business Research, 11(11), 37-45.

Salvetat, D., Géraudel, M., \& d'Armagnac, S. (2013). Inter-organizational knowledge management in a coopetitive context in the aeronautic and space industry. Knowledge Management Research \& Practice, 11(3), 265-277.

Sarstedt, M., Hair, J. F., Ringle, C. M., Thiele, K. O., \& Gudergan, S. P. (2016). Estimation issues with PLS and CBSEM: Where the bias lies!. Journal of Business Research, 69(10), 3998-4010.

Selnes, F., \& Sallis, J. (2003). Promoting relationship learning. Journal of Marketing, 67(3), 80-95.

Slater, S. F. \& Narver, J. C. (1998). Customer-led and market-oriented: let's not confuse the two. Strategic Management Journal, 19 (10), 1001-1006.

Smith, J. B. and Colgate, M. (2007). Customer value creation: a practical framework. Journal of Marketing Theory \& Practice, 15 (1), 7-23.

Spiteri, J. M. and Dion, P. A. (2004), Customer value, overall satisfaction, end-user loyalty, and market performance in detail intensive industries. Industrial Marketing Management, 33 (8), 675-687.

Taylor, A. B., MacKinnon, D. P., \& Tein, J. Y. (2008). Tests of the three-path mediated effect. Organizational Research Methods, 11(2), 241-269.

Vargo, S. L., \& Lusch, R. F. (2004). Evolving to a new dominant logic for marketing. Journal of Marketing, 68(1), 1-17.

Vargo, S. L., \& Lusch, R. F. (2008). Service-dominant logic: continuing the evolution. Journal of the Academy of marketing Science, 36(1), 1-10.

Von Hippel, E. (1994). "Sticky information" and the locus of problem solving: implications for innovation. Management Science, 40(4), 429-439.

Williams, J., \& MacKinnon, D. P. (2008). Resampling and distribution of the product methods for testing indirect effects in complex models. Structural Equation Modeling, $15(1), 23-51$.

Yang, C. F., \& Lai, C. S. (2012). Relationship learning from organizational knowledge stores. Journal of Business Research, 65(3), 421-428. 
1 2 3 4 5 6
Zaltman, G., Duncan, R., Holbeck, J. (1973). Innovation and Organizations. Wiley, New York.

Zhang, M., Guo, L., Hu, M., \& Liu, W. (2017). Influence of customer engagement with company social networks on stickiness: Mediating effect of customer value creation. International Journal of Information Management, 37(3), 229-240.

Zhou, K. Z., Yim, C. K., \& Tse, D. K. (2005). The effects of strategic orientations on technology and market-based breakthrough innovations. Journal of Marketing, 69, 4260 . 
Table 1. Questionnaire scales and items

\begin{tabular}{|c|c|}
\hline Construct & Items \\
\hline $\begin{array}{l}\text { Relationship learning } \\
\text { (Information sharing) } \\
\text { Selnes \& Sallis (2003) }\end{array}$ & $\begin{array}{l}\text { - We exchange information on successful and unsuccessful experiences with products exchanged } \\
\text { in the relationship with partners and suppliers } \\
\text { - We exchange information related to changes in end-user needs, preferences, and behavior } \\
\text { - We exchange information related to changes in market structure, such as mergers, acquisitions, } \\
\text { or partnering } \\
\text { - We exchange information related to changes in the technology of the focal products } \\
\text { - We exchange information as soon as any unexpected problems arise } \\
\text { - We exchange information related to changes in the organizations' strategies and policies } \\
\text { - We exchange information that is sensitive, such as financial performance and know-how }\end{array}$ \\
\hline $\begin{array}{l}\text { Relationship learning } \\
\text { (Joint sensemaking) } \\
\text { Selnes \& Sallis (2003) }\end{array}$ & $\begin{array}{l}\text { - It is common to establish joint teams to solve operational problems in the relationships with } \\
\text { partners, suppliers and customers } \\
\text { - It is common to establish joint teams to analyze and discuss strategic issues in the relationship } \\
\text { with partners, suppliers and customers } \\
\text { - The atmosphere in the relationship with partners, suppliers and customers stimulates productive } \\
\text { discussion that encompasses a variety of opinions } \\
\text { - We have a lot of face-to-face communication in this relationship }\end{array}$ \\
\hline $\begin{array}{l}\text { Relationship learning } \\
\text { (Knowledge } \\
\text { integration) Selnes \& } \\
\text { Sallis (2003) }\end{array}$ & $\begin{array}{l}\text { - We frequently adjust our common understanding of end user's needs and behavior } \\
\text { - We frequently adjust our common understanding of trends in technology related to our business } \\
\text { - We frequently evaluate and, if needed, adjust our routines in order-delivery processes } \\
\text { - We frequently evaluate and, if needed, update the formal contracts in our relationship } \\
\text { - We frequently meet face-to-face to refresh the personal network in this relationship } \\
\text { - We frequently evaluate and, if needed, update information about the relationship stored in our } \\
\text { electronic databases }\end{array}$ \\
\hline $\begin{array}{c}\text { Organizational } \\
\text { innovativeness } \\
\text { Hurley \& Hult (1998) }\end{array}$ & $\begin{array}{l}\text { - Technical innovation, derived from research, is immediately accepted } \\
\text { - The firm's management actively seeks innovative ideas } \\
\text { - Innovation in the management of processes, projects and programmes is immediately accepted } \\
\text { - The staff is not penalized by the development of ideas that finally do not work }\end{array}$ \\
\hline $\begin{array}{l}\text { Customer value } \\
\text { Rust et al. (2001) }\end{array}$ & $\begin{array}{ll}\text { - } & \text { Customers' satisfaction } \\
\text { - } & \text { Customers' loyalty } \\
\text { - } & \text { Customers acquisition } \\
\end{array}$ \\
\hline
\end{tabular}


1 2 3 4 5 8 10 11 12 13 14 15

Table 2. Measurement Model: Outer loadings

\begin{tabular}{|c|c|c|c|c|c|}
\hline \multicolumn{6}{|c|}{ Outer loadings } \\
\hline $\begin{array}{c}\text { Outer } \\
\text { loadings }\end{array}$ & $\begin{array}{c}\mathrm{RL} \\
\text { (Information } \\
\text { sharing) }\end{array}$ & $\begin{array}{c}\text { RL (Joint } \\
\text { sensemaking) }\end{array}$ & $\begin{array}{c}\text { RL } \\
\text { (Knowledge } \\
\text { integration) }\end{array}$ & $\begin{array}{l}\text { Organizational } \\
\text { innovativeness }\end{array}$ & $\begin{array}{c}\text { Customer } \\
\text { value }\end{array}$ \\
\hline ISH1 & 0.866 & & & & \\
\hline ISH2 & 0.912 & & & & \\
\hline ISH3 & 0.758 & & & & \\
\hline ISH4 & 0.795 & & & & \\
\hline ISH5 & 0.819 & & & & \\
\hline ISH6 & 0.813 & & & & \\
\hline JSM1 & & 0.907 & & & \\
\hline JSM2 & & 0.873 & & & \\
\hline JSM4 & & 0.799 & & & \\
\hline KI1 & & & 0.789 & & \\
\hline KI2 & & & 0.992 & & \\
\hline KI3 & & & 0.992 & & \\
\hline KI4 & & & 0.992 & & \\
\hline KI5 & & & 0.992 & & \\
\hline KI6 & & & 0.992 & & \\
\hline OI1 & & & & 0.904 & \\
\hline OI2 & & & & 0.938 & \\
\hline OI3 & & & & 0.891 & \\
\hline OI4 & & & & 0.889 & \\
\hline CV1 & & & & & 0.915 \\
\hline $\mathrm{CV} 2$ & & & & & 0.918 \\
\hline
\end{tabular}


Table 3. Measurement model: Construct reliability, convergent validity and discriminant validity

\begin{tabular}{lccc}
\hline \multicolumn{3}{c}{ Construct Reliability and Convergent Validity } \\
\hline & rho_A & Composite Reliability & $\begin{array}{c}\text { Average } \\
\text { Variance } \\
\text { Extracted (AVE) }\end{array}$ \\
\hline $\begin{array}{c}\text { Relationship } \\
\text { learning }\end{array}$ & 0.834 & 0.895 & 0.741 \\
$\begin{array}{c}\text { Organizational } \\
\text { innovativeness } \\
\text { Customer } \\
\text { value }\end{array}$ & 0.737 & 0.884 & 0.792 \\
\hline
\end{tabular}

\begin{tabular}{|c|c|c|c|}
\hline \multicolumn{4}{|c|}{ Discriminant Validity: Heterotrait-Monotrait Ratio (HTMT) } \\
\hline & $\begin{array}{l}\text { Relationship } \\
\text { learning }\end{array}$ & $\begin{array}{l}\text { Organizational } \\
\text { innovativeness }\end{array}$ & Customer value \\
\hline $\begin{array}{c}\text { Relationship } \\
\text { learning }\end{array}$ & & & \\
\hline $\begin{array}{l}\text { Organizational } \\
\text { innovativeness }\end{array}$ & 0.533 & & \\
\hline $\begin{array}{l}\text { Customer } \\
\text { value }\end{array}$ & 0.101 & 0.037 & \\
\hline
\end{tabular}

\begin{tabular}{cccc}
\hline \multicolumn{4}{c}{ Discriminant Validity: Fornell-Larcker criterion } \\
\hline & $\begin{array}{c}\text { Relationship } \\
\text { learning }\end{array}$ & $\begin{array}{c}\text { Organizational } \\
\text { innovativeness }\end{array}$ & Customer value \\
\hline $\begin{array}{c}\text { Relationship } \\
\text { learning }\end{array}$ & 0.916 & & \\
$\begin{array}{c}\text { Organizational } \\
\text { innovativeness } \\
\text { Customer } \\
\text { value }\end{array}$ & 0.323 & 0.921 & \\
\hline
\end{tabular}

Notes: Rho A: Dijkstra-Henseler's indicator; AVE: average variance extracted. Fornell-Larcker Criterion: Diagonal elements (italics) are the square root of the variance shared between the constructs and their measures (AVE). For discriminant validity, diagonal elements should be larger than off-diagonal elements. Off-diagonal elements are the correlations among constructs. Heterotrait-Monotrait Ratio (HTMT) criterion should be under the threshold of 0.85 (Kline, 2015). 
Table 4. Structural model results

\begin{tabular}{|c|c|c|c|c|}
\hline \multirow{4}{*}{ Relationship } & \multicolumn{2}{|l|}{ Model 1} & \multicolumn{2}{|l|}{ Model 2} \\
\hline & \multirow{2}{*}{\multicolumn{2}{|c|}{$\mathrm{R}^{2} \mathrm{CV}=0.245$}} & \multirow{2}{*}{\multicolumn{2}{|c|}{$\begin{aligned} \mathrm{R}^{2} \mathrm{CV} & =0.270 \\
\mathrm{R}^{2} \mathrm{OI} & =0.197\end{aligned}$}} \\
\hline & & & & \\
\hline & $\begin{array}{l}\text { Path coefficient } \\
\text { (t-statistic) }\end{array}$ & p-value & $\begin{array}{l}\text { Path coefficient } \\
\text { (t-statistic) }\end{array}$ & p-value \\
\hline $\mathrm{RL} \rightarrow \mathrm{CV}$ & $\begin{array}{c}0.356 * * *(5.018) \\
{[0.250 ; 0.556]}\end{array}$ & 0.000 & $\begin{array}{c}0.233 * * *(3.650) \\
{[0.203 ; 0.543]}\end{array}$ & 0.000 \\
\hline $\mathrm{RL} \rightarrow \mathrm{OI}$ & & & $\begin{array}{c}0.487 * * *(7.729) \\
{[0.364 ; 0.611]}\end{array}$ & 0.000 \\
\hline $\mathrm{OI} \rightarrow \mathrm{CV}$ & & & $\begin{array}{l}0.208 *(2.098) \\
{[0.096 ; 0.501]}\end{array}$ & 0.036 \\
\hline $\begin{array}{l}\text { Indirect effect } \\
(\mathrm{RL} \rightarrow \mathrm{OI} \rightarrow \mathrm{CV})\end{array}$ & & & $\begin{array}{l}0.101 *(2.044) \\
{[0.005 ; 0.196]}\end{array}$ & 0.041 \\
\hline
\end{tabular}

Notes: t-values in parentheses. Bootstrapping 95\% confidence intervals bias corrected in square brackets (based on $\mathrm{n}=5000$ subsamples). $* * * \mathrm{p} \mathrm{b} .001 ; * * \mathrm{p} \mathrm{b} .01 ; * \mathrm{p} \mathrm{b} .05$ (based on $\mathrm{t}(4999)$, one-tailed test). $\mathrm{t}(0.05$, $4999)=1.645 ; \mathrm{t}(0.01,4999)=2.327 ; \mathrm{t}(0.001,4999)=3.092 ; \mathrm{ns}=$ not significant. 
Figure 1. Conceptual model and hypotheses

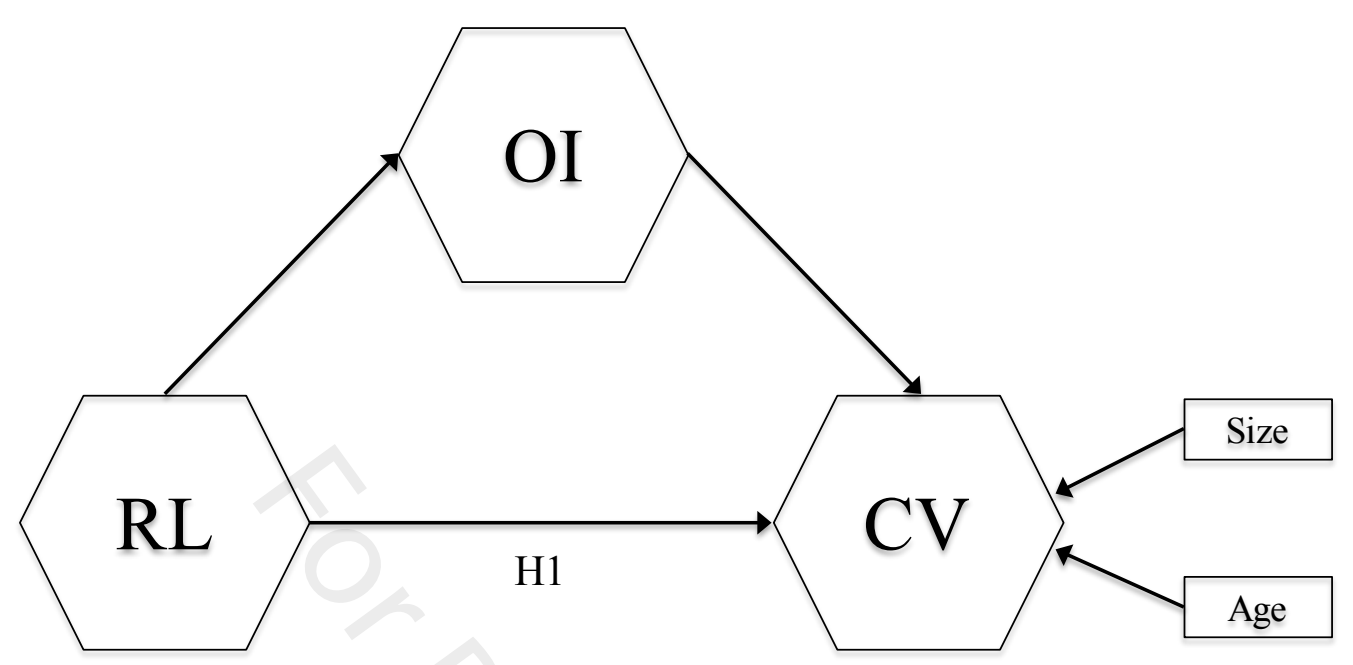

$\mathrm{H} 2: \mathrm{RL} \rightarrow \mathrm{OI} \rightarrow \mathrm{CV}$

Note: RL: Relationship Learning; OI: Organizational Innovativeness; CV: Customer Value. 